\title{
Development of Rabbit's Anti-Pig Serum Polyclonal Antibodies to Detect Pork Adulteration in Meat Products
}

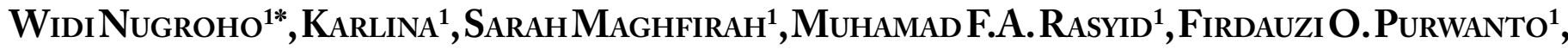 Muhammad A. Lesmana ${ }^{2}$, Siska Aditya ${ }^{3}$}

\begin{abstract}
${ }^{1}$ Laboratory of Veterinary Public Health, Faculty of Veterinary Medicine, Universitas Brawijaya, Kalisongo, Dau, Malang, East Java, Indonesia, 65151; ${ }^{2}$ Laboratory of Veterinary Surgery, Faculty of Veterinary Medicine, Universitas Brawijaya, Kalisongo, Dau, Malang, East Java, Indonesia, 65151; ${ }^{3}$ Laboratory of Veterinary Biochemistry, Faculty of Veterinary Medicine, Universitas Brawijaya, Kalisongo, Dau, Malang, East Java, Indonesia, 65151.
\end{abstract}

\begin{abstract}
This study aimed to produce rabbit's anti-pig serum polyclonal antibodies, as part of an attempt to develop a rapid, reliable, and self-administered test for detecting pork adulteration in meat products. The pig antigen for the antibody production was obtained by the treatment of pig serum using $10 \%$ caprylic acid. Experimental immunization of rabbits using the pig antigen demonstrated that antibodies were detectable on day 56 post-initial immunization. The antibodies were capable of detecting pork juice at as low as 1\% dilution. Further, the antibodies reacted specifically to pork amongst juices of pork, beef, lamb, goat, duck, and catfish meat species tested. This study provides extended knowledge for the development of a rapid, and self-administered test for detecting pork adulteration in meat products.
\end{abstract}

Keywords | Pork adulteration, Pig antigen, Caprylic acid, Rabbit's anti-pig serum polyclonal antibodies, Agar gel immunodiffusion

Received | May 20, 2021; Accepted | August 16, 2021; Published | September 25, 2021

*Correspondence | Widi Nugroho, Laboratory of Veterinary Public Health, Faculty of Veterinary Medicine, Universitas Brawijaya, Kalisongo, Dau, Malang, East Java, Indonesia, 65151; Email: widi.nugroho@ub.ac.id

Citation | Nugroho W, Karlina, Maghfirah S, Rasyid MFA, Purwanto FO, Lesmana MA, Aditya S (2021). Development of rabbit's anti-pig serum polyclonal antibodies to detect pork adulteration in meat products. Adv. Anim. Vet. Sci. 9(11): 1919-1924.

DOI | http://dx.doi.org/10.17582/journal.aavs/2021/9.11.1919.1924

ISSN (Online) | 2307-8316; ISSN (Print) | 2309-3331

Copyright $@ 2021$ Nugroho et al. This is an open access article distributed under the Creative Commons Attribution License, which permits unrestricted use, distribution, and reproduction in any medium, provided the original work is properly cited.

\section{INTRODUCTION}

$\mathrm{P}$ ork adulterations are illegal for religious, health, or economic reasons (Ali et al., 2014; Kwon et al., 2013; Oh et al., 2004; Ramos and Canseco, 1993; Rentzos et al., 2019; Rohman et al., 2011). Pork is obviously not halal and pork consumption is religiously forbidden for two billion Muslims worldwide (Kettani, 2019). Pork adulteration can be dangerous for allergic populations. It comprises, for example, $6.8-10.2 \%$ of food allergy prevalence in Seoul, South Korea $(\mathrm{n}=755-1299), 8.8 \%(\mathrm{n}=247)$ in Monclova, Mexico, and 0.6\% ( $\mathrm{n}=1042)$ in Västra Götaland, Sweden (Kwon et al., 2013; Oh et al., 2004; Ramos and Canseco, 1993; Rentzos et al., 2019). Yet, undeclared pork content in meat products has been detected in many countries. Studies in the world's largest Muslim populated country,
Indonesia, reported that pork adulteration occurred in $7.9 \%(n=33)$ of halal meat products in Bogor (Nida et al., 2020), and 20.0\% $(n=10)$ in Yogyakarta (Admantin and Santoso, 2013). Pork adulteration was also reported in 8.6\% $(\mathrm{n}=35)$ of meat products in South Korea (Jimyeong Ha et al., 2017) and 25.6\% $(\mathrm{n}=250)$ in Sichuan China (Song et al., 2019). Lack of affordable self-administered tests however, hamper consumers from being able to protect themselves from unpleasant or even detrimental effects of pork adulteration.

Efforts to develop pork detection in meat products that is easily applied by consumers have been reported. A test targeted pig-specific DNA using the LFA showed the result at as soon as 30 minutes (Magiati et al., 2019). The pig DNA fragment remains detectable in a heated meat 
product $\left(200^{\circ} \mathrm{C}\right.$ for 20 minutes $)$, a seasoned pork salami, and a sausage (Ulca et al., 2013). However, due to the time length needed to complete the test, it may not be convenient when it is self-administered by consumers. Another strip test for pork detection based on DNA probing was developed and was capable of detecting pork in as soon as three minutes (Yin et al., 2020), but the sample has to be incubated at $35^{\circ} \mathrm{C}$ before it can be tested in the strip, a practice that may not be suitable for consumers in many daily life situations.

Immunocensor based tests to detect pork in meat products have also been reported. A test based on an anti-pig-albumin antibody was used for detecting porcine albumin in meat products but, with the electrochemical immunocensor method described, the optimum detection was obtained only after a 45-minute incubation (Lim and Ahmed, 2016). The ELISA based on monoclonal antibodies against thermal-stable fat protein of pigs, thermal-stable muscle protein of pigs or pig's haemoglobin also have been developed. While showed excellent sensitivities and specificities, the applications of these tests were only readable after as soon as 45 minutes (Chen and Hsieh, 2000; Li et al., 2020).

A few rapid lateral flow assays (LFA) based on anti-pigIgG polyclonal antibodies coupled with gold nanoparticles were capable of showing the test results within 2-10 minutes when were applied to both raw and cooked meat products (Depamede, 2011; Kuswandi et al., 2017; Mandli et al.,2018). Compared to other test formats, the lateral flow immunocencor test of pork adulteration is characterised as lower in cost, less time consuming, highly specific, can be done by consumers with very simple or no training, but the commercial test is currently not available (Li et al., 2020). One of the key components to manufacturing this test is the availability of anti-pig-IgG antibodies (Kuswandi et al., 2017).

To date, the production of monoclonal antibodies against pig-IgG to detect pork adulteration in meat products have not been reported ( $\mathrm{Li}$ et al., 2020). Production of monoclonal antibodies though, when compared to polyclonal antibodies, takes longer time. It also employs more complex steps of immunisation, fusion of lymphocyte with myeloma, and culture of hybridoma cells, which need more sophisticated equipments thus can be more expensive (Wakayama et al., 2006). In fact, polyclonal antibodies against pig IgG used in an immunocencor to detect pork adulteration was capable of detecting the pork content up to $0.1 \%$, without cross reactivity with beef (Kuswandi et al., 2017). These might underline the less importance of producing monoclonal antibodies against pig-IgG for pork detection.
The IgG and Albumin are two main components of blood plasma and the extracellular fluid of the vertebrate tissues (Brekke et al., 2010; Charles et al., 2001), making both molecules potential markers to detect pork adulteration in meat products. Immunoglobulin and Albumin can be extracted from a serum sample by simple caprylic acid (CA) treatment to precipitate other serum protein impurities (Morais and Massaldi, 2012; Shawki et al., 2017). The extraction and purification of pig immunoglobulin by $\mathrm{CA}$ and the capability of the filtrate to bind to specific antibodies in-vitro were reported (Bokhout et al., 1986). However, the study is lacking on the use of simple CA extract of the pig serum as a polyvalent antigen for the production of specific antibodies to detect pig species in a meat product. Provided that immunocensor based tests for pork detection have a potential for rapid and easy application by consumers, lower-cost production of the materials for fabrication of the test tool, including the production of antigen and the specific antibodies, warrant investigations.

The aim of this study, therefore, was to investigate the production, sensitivity, and specificity of an anti-pig polyclonal antibody against pig serum antigen extracted using CA, in New Zealand rabbits (Oryctolagus cuniculus). The sample used in this study was serum isolated from blood of a Landrace pig. This study provides essential knowledge for the development of rapid, reliable, self-administered, and easy to use tests for detecting pork adulteration in meat products.

\section{MATERIALS AND METHODS}

\section{ETHICAL CONSIDERATION}

The study was approved by the Animal Care and Use Committee of Universitas Brawijaya in document number 046-KEP-UB-2020. Experiment with animals was conducted in the Experimental Animal Facility, Faculty of Veterinary Medicine, Universitas Brawijaya.

\section{SUPPLIES OF ANIMALS AND MEATS}

Three individual rabbits were used to produce anti-pig polyclonal antibodies. Four months of age, male, New Zealand White rabbits (Oryctolagus cuniculus) weighing 2.2 $\mathrm{kg}(\mathrm{SD} \pm 0.1)$ were supplied by a local breeder in Malang, East Java, Indonesia. The serum of a Landrace pig's blood as the source of antigen was obtained from the Kota Malang slaughterhouse. Pork, beef, lamb, goat, duck, and catfish meats for the species specificity tests were obtained from Gadang wet market in Malang.

\section{ANTIGEN PREPARATION}

Pig antigen was prepared by extraction of pig serum using CA with some modifications (Bokhout et al., 1986; Morais 
and Massaldi, 2012). The extraction was conducted in $\mathrm{pH}$ 5 , and the final concentration of the CA was $10 \%$ (SigmaAldrich, St. Louis, Missouri, USA). Briefly, $20 \mathrm{~mL}$ pig serum was added to distilled water (OTSUKA, Surabaya, Indonesia), and CA was added drop by drop into the solution along with stirring, to a final volume of $40 \mathrm{~mL}$. The mixture was vortexed for 15 minutes and subsequently centrifuged (Monota RO, Osaka, Japan) at 60,000 $\mathrm{g}$ for 20 minutes. The supernatant was filtered with Whatman paper No. 2 (Sigma Aldrich, St. Louis, Missouri, USA), and stored at $-20^{\circ} \mathrm{C}$ until use.

\section{Preparation of PIg SERUM ANTIGeN For} IMMUNIZATION

The protein concentration of the pig antigen was analyzed using a Nano Drop $1000^{\mathrm{TM}}$ Spectrophotometer (Thermofisher, Waltham, MA, USA). A $2 \mu \mathrm{L}$ of the pig antigen was used, and the protein concentration was estimated at $280 \mathrm{~nm}$ wavelength. The pig antigen was emulsified with Freund's complete adjuvant (G-Biosciences, St. Louis, Missouri, USA) at a final concentration of $10 \%$ $(\mathrm{v} / \mathrm{v})$ of total emulsion. The mixture was vortexed for 10 minutes, and the formation of the emulsion was tested on a water surface; small particles dispersed evenly on the surface of the water were considered proper emulsion formation (Leenaars et al., 1999).

\section{IMMUNIZATION OF ANIMALS}

After a week of acclimatization, each of the animals was injected with $875 \mu \mathrm{g}$ pig serum antigen at a volume of $100 \mu \mathrm{L}$ subcutaneously, using a one $\mathrm{mL}$ syringe with $26 \mathrm{G}$ needle. The immunization was repeated on days $7,14,21$, and 28 after the initial immunization. Animals were bled from auricular veins using $3 \mathrm{~mL}$ syringes with $22 \mathrm{G}$ needle on day one just before the initial immunization, and on days 14,36 , and 56 after the initial immunization to analyse the development of antibodies against the pig antigen. On day 56 post-initial injection, all animals were euthanized by anesthesia followed by exsanguination, bloods were collected, and sera were extracted and stored at $-20^{\circ} \mathrm{C}$ for further analyses (Leary et al., 2020).

\section{Detection of ANTIBOdies AGAINST PIG SERUM} ANTIGEN

The detection of the formation of antibodies against pig antigen in immunized animals was conducted qualitatively using Agar Gel Immunodiffusion (AGID) test. Sera of experimental animals collected on day one before the initial immunization was used as the negative controls. A $1 \%$ agarose (Sigma-Aldrich, St. Louis, Missouri, USA) in 1\% Phosphate Buffered Saline (PBS) (Sigma-Aldrich, St. Louis, Missouri, USA) was used in this test (da Cunha et al., 2015). A $13 \mathrm{~mL}$ of the liquid agarose was poured into a $20 \mathrm{~cm}$ diameter petri dish to form a gel. A $4 \mathrm{~mm}$ diameter well was punched in the center of the gel and four wells with the same diameter were punched around the central well. A $20 \mu \mathrm{L}$ pig antigen was dropped into the central well, and $20 \mu \mathrm{L}$ of rabbit sera collected on days $1,14,36$, and 56 were dropped into wells designed around the central well. The gel was incubated for $48 \mathrm{~h}$ in a humid condition, at $37^{\circ} \mathrm{C}$. A white precipitation line developed between the central well contained pig antigen and the well contained serum of the immunized rabbits was deemed to indicate the formation of anti-pig antibodies.

DETERMINATION OF THE SPECIES SPECIFICITY OF THE RABBIT'S ANTI-PIG POLYCLONAL ANTIBODIES (RAPSАв)

Meat juices from bovine (Musculus pectoralis), goats (Musculus pectoralis), sheep (Musculus pectoralis), duck (Musculus pectoralis), and catfish (Musculus epaxialis) meat were used for this purpose. They were used in this study to represent different classes of animals from pisces, aves and mammals. Additionally, for duck and ruminant meats, the similarity in gross appearance with pork, their popularity in local context and higher prices compared to pork were considerations to include them as the subjects of the study. The meat juices were obtained by freezing the meats at $-20^{\circ} \mathrm{C}$ followed by thawing, and juices were collected into sterile tubes, one for each species (Cybulska et al., 2020). Samples were stored at $-20^{\circ} \mathrm{C}$ until use.

Determination of species specificity of the hyperimmune serum was determined using AGID with the same procedures described above (da Cunha et al., 2015). The central well was filled in with the hyperimmune serum and the surrounding wells were filled in with juices of the aforementioned meat species. Pork juice and the pig antigen were used as positive controls.

\section{DETERMINATION OF THE SENSITIVITY OF THE TEST}

An analytical sensitivity test using AGID was performed to investigate the limit of the antigen concentration that remains detectable by the hyperimmune serum (da Cunha et al., 2015). Concentrations of 50\%, 40\%, 30\%, 20\%, $10 \%$, $5 \%, 2.5 \%$, and $1 \%$ of the pig antigen were used in the test. In this test, the hyperimmune serum was dropped into the central well and the diluted pig antigens were filled into surrounding wells.

\section{RESULTS AND DISCUSSION}

An attempt to produce a low-cost RaPS-Ab to detect pork adulteration was reported. In this experiment, the extraction of pig antigen from serum using CA was capable of producing a total soluble protein of $17.5 \mathrm{mg} /$ $\mathrm{mL}$ from a total serum protein of $46.1 \mathrm{mg} / \mathrm{mL}$. However, the true serum protein(s) contained remains unknown and 
warranted further analysis.

It is likely that the pig antigen utilized in current study mainly contained pig Albumin or Immunoglobulin. The extraction of pig antigen using CA was reported to retain immunoglobulin Gamma in the filtrate (Bokhout et al., 1986). Other studies reported that treatments of equine and Camel sera using CA resulted in two major proteins in the filtrates: Albumin and immunoglobulin (Morais and Massaldi, 2012; Shawki et al., 2017). Albumin and Immunoglobulin can be good candidates as markers to detect pork adulteration in raw or cooked meat products. The concentration of albumin in pork is $\sim 5 \mathrm{mg} / \mathrm{L}$ (Moon et al., 2014) and it retains one-tenth of its affinity to immunoglobulin even after autoclaving (Lee et al., 2011). The resistance of Immunoglobulin under autoclaving is unknown, but in meatball samples boiled for 20 minutes, the pig immunoglobulin remained detectable using a polyclonal-antibody based lateral flow test (Kuswandi et al., 2017).

The study demonstrated that the pig antigen extracted with a simple method of caprylic acid precipitation was sufficient for producing an immunogenic pig-specific antigen. The AGID tests showed that the RaPS-Ab were detected on day 56 after initial immunization (Figure 1A). The specificity test showed that the antibodies reacted specifically with pork juice amongst five different meat species used in the test (Figure 1B). The AGID test further showed that the antibodies were capable of detecting pig antigen in as low as $1 \%$ of its initial concentration (Figure $1 \mathrm{C})$. Another simple method to purify IgG for antigen preparation to produce anti $\operatorname{IgG}$ antibodies, consisted of two steps, included precipitation with saturated ammonium sulphate and an overnight dyalisis (Majidi et al., 2007; Sadeghi et al., 2018). Compared to this, the CA precipitation provides a simpler procedure in term of time consumed and resources allocated.
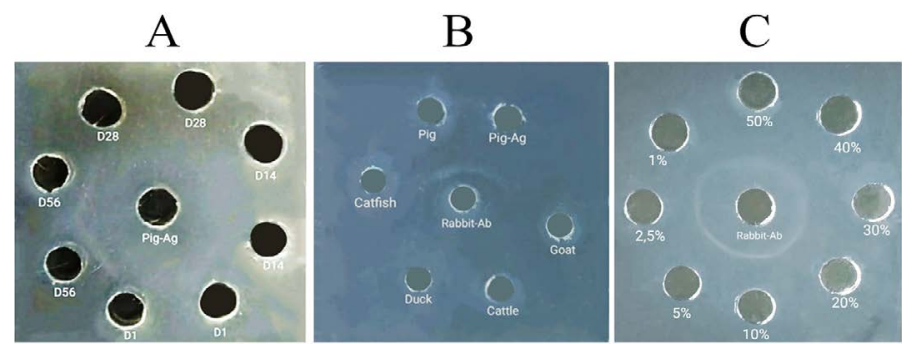

Figure 1: A, The formation of rabbit anti-pig serum antibodies (RaPS-Ab) was detectable on day 56 post initial immunization (D1, D14, D36, D56 represent day after initial immunization); $\mathrm{B}$, The RaPS-Ab reacted specifically to pork juice (Pig) and pig antigen amongst meat juices tested; C, Sensitivity test shows that the RaPS$\mathrm{Ab}$ detected the pig antigen at as low as $1 \%$ dilution. (RaPS-Ab: Rabbit-Ab; pig antigen: Pig-Ag).
The final bleeding of the experimental animals yielded $\sim 24 \mathrm{~mL}$ serum from the individual rabbit weighed two kilograms. The use of rabbits as the biological machine to produce the anti-pig antibodies may be sufficient to facilitate a large survey of 1,000 individual meat samples in a population when the AGID is to be used. For the production of a higher titer of antibodies in a rabbit, a longer time period of animal keeping or better use of Freud's complete adjuvant might be needed (Bollen et al., 1996). In addition, the production of anti-pig antibodies in larger animal species using pig antigen extraction described in this study, as an alternative to producing lower cost and more efficient anti-pig antibodies, is open for investigations.

The affinity of the pig antigen in meat products to its specific antibodies however, can be influenced by various seasoning substances (Moon et al., 2014). On the other side, the cross-reaction of the anti-pig antibodies to different types of marinations remains unknown and further study is needed to answer this question. Further study is also advisable to develop a rapid lateral flow test described earlier (Kuswandi et al., 2017) using antibodies developed by the current method.

In conclusions, this study provides a proof of concept that pig antigen extracted from pig serum by the simple step of impurities precipitation using $\mathrm{CA}$ is capable of inducing pig species-specific antibodies in rabbits and the antibodies have the potential as a sensitive tool to detect low level of pork adulteration or contamination in various raw or cooked meat products.

\section{ACKNOWLEDGEMENTS}

This study is funded by The Institute of Research and Community Services (LPPM) Universitas Brawijaya, through contract number 436.37/UN10.C10/PN/2020.

\section{NOVELTY STATEMENT}

To the best of our knowledge, this is the first report of the use of simple Caprilic acid extract of the pig serum as a polyvalent antigen for the production of specific antibodies to detect pig species in a meat product.

\section{AUTHOR'S CONTRIBUTION}

WN conceptualization, formal analysis, funding acquisition, methodology, project administration, resources, supervision, validation, visualization, writingoriginal draft, writing review and editing. $\mathrm{K}, \mathrm{SM}, \mathrm{FAR}$ and FOP data curation, investigation, methodology, project administration, resources, software, visualization, 
writing-original draft. MAL data curation, formal analysis, funding acquisition, methodology, resources, supervision, writing original draft, writing review and editing. SA conceptualization, formal analysis, methodology, resources, supervision, visualization, writing original draft, writing review and editing.

\section{CONFLICT OF INTEREST}

The authors have declared no conflict of interest.

\section{REFERENCES}

-Admantin CY, Santoso IU (2013). Identifikasi Pemalsuan produk bakso sapi dengan daging babi dan daging ayam menggunakan metode porcine detection-kit dan multiplex polymerase chain reaction. Doctoral Dissertation. Universitas Gadjah Mada, Yogyakarta.

-Ali M, Hashim U,Mustafa S, Che Man Y, Adam T,Humayun Q (2014). Nanobiosensor for the detection and quantification of pork adulteration in meatball formulation. J. Exp. Nanosci., 9: 152-160. https://doi.org/10.1080/17458080.2 011.640946

-Bokhout B, van Asten-Noordijk J, Stok W (1986). Porcine IgG. Isolation of two IgG-subclasses and anti-IgG class-and subclass-specific antibodies. Mol. Immunol., 23: 675-683. https://doi.org/10.1016/0161-5890(86)90106-9

- Bollen LS, Crowley A, Stodulski G, Hau J (1996). Antibody production in rabbits and chickens immunized with human IgG A comparison of titre and avidity development in rabbit serum, chicken serum and egg yolk using three different adjuvants. J. Immunol. Methods. 2(191): 113-120.

-Brekke H, Oveland E, Kolmannskog O, Hammersborg S, Wiig H, Husby P, Tenstad O, Nedrebø T (2010). Isolation of interstitial fluid in skin during volume expansion: evaluation of a method in pigs. Am. J. Physiol. Heart Circ. Physiol., 299: H1546-H1553. https://doi.org/10.1152/ ajpheart.01142.2009

- Charles A, Janeway J, Paul T, Mark W, Shlomchik MJ (2001). Immunobiology: The immune system in health and disease. $5^{\text {th }}$ edition New York: Garland Science.

- Chen FC, Hsieh YP (2000). Detection of pork in heatprocessed meat products by monoclonal antibody-based ELISA. J. AOAC Int., 83: 79-85. https://doi.org/10.1093/ jaoac/83.1.79

- Cybulska A, Kornacka A, Popiołek M, Bień-Kalinowska J, Moskwa B (2020). Use of meat juice from racoons (Procyon lotor) collected from Central Europe for immunological detection of Trichinella spp. Vet. Parasitol., pp. 109066. https://doi.org/10.1016/j.vetpar.2020.109066

- da Cunha MdRO, de Siqueira ACA, Leite AS, Freitas LT, Gonzalez JC, de Assis SVL, Manso-Filho HC (2015). Comparison of two protocols of agar gel immunodiffusion (AGID) used to diagnose of Equine Infectious Anemia (EIA). Open J. Vet. Med., 5: 169. https://doi.org/10.4236/ ojvm.2015.57023

-Depamede S (2011). Development of a rapid immunodiagnostic test for pork components in raw beef and chicken meats: A preliminary study. Media Peternakan, 34: 83. https://doi. org/10.5398/medpet.2011.34.2.83

- Jimyeong H, Sejeong K, Jeeyeon L, Soomin L, Heeyoung L, Yukyung C, Hyemin O, Yoon Y (2017). Identification of pork adulteration in processed meat products using the developed mitochondrial dna-based primers. Korean J. Food Sci. Anim. Resour., 37: 464-468. https://doi.org/10.5851/ kosfa.2017.37.3.464

-Kettani H (2019). The world muslim population: Spatial and temporal analyses. CRC Press, New York, pp. 916. https:// doi.org/10.1201/9780429422539

- Kuswandi B, Gani AA, Ahmad M (2017). Immuno strip test for detection of pork adulteration in cooked meatballs. Food Biosci., 19: 1-6. https://doi.org/10.1016/j.fbio.2017.05.001

-Kwon J, Kim J, Cho S, Noh G, Lee SS (2013). Characterization of food allergies in patients with atopic dermatitis. Nutr. Res. Pract., 7: 115-121. https://doi.org/10.4162/ nrp.2013.7.2.115

- Leary S, Underwood W, Anthony R, Cartner S, Grandin T, Greenacre C, Gwaltney-Brant S, McCrackin M, Meyer R, Miller D (2020). AVMA guidelines for the euthanasia of animals: 2020 Edition. AVMA Am. Vet. Med. Assoc., Schaumburg, IL, USA.

-Lee SY, Song EJ, Kim KE, Ahn DH (2011). Effect of heat and autoclave on allergenicity of porcine serum albumin. Food Sci. Biotechnol., 20: 455-459. https://doi.org/10.1007/ s10068-011-0063-0

- Leenaars PM, Hendriksen CF, de Leeuw WA, Carat F, Delahaut P, Fischer R, Halder M, Hanly WC, Hartinger J, Hau J (1999). The production of polyclonal antibodies in laboratory animals: The report and recommendations of ECVAM workshop 35. ATLA, 27: 79-102. https://doi. org/10.1177/026119299902700106

- Li YC, Liu SY, Meng FB, Liu DY, Zhang Y, Wang W, Zhang JM (2020). Comparative review and the recent progress in detection technologies of meat product adulteration. Comprehen. Rev. Food Sci. Food Saf., 19: 2256-2296. https://doi.org/10.1111/1541-4337.12579

- Lim SA, Ahmed MU (2016). A label free electrochemical immunosensor for sensitive detection of porcine serum albumin as a marker for pork adulteration in raw meat. Food Chem., 206: 197-203. https://doi.org/10.1016/j. foodchem.2016.03.063

- Magiati M, Myridaki V, Christopoulos T, Kalogianni D (2019). Lateral flow test for meat authentication with visual detection. Food Chem., 274: 803. https://doi.org/10.1016/j. foodchem.2018.09.063

- Majidi J, Abdolalizadeh J, Amirkhiz M, Majidi S (2007). Production and purification of polyclonal antibody against bovine immunoglobulins in rabbits. Afr.J. Biotechnol., pp. 6.

-Mandli J, Fatimi IE, Seddaoui N, Amine A (2018). Enzyme immunoassay (ELISA/immunosensor) for a sensitive detection of pork adulteration in meat. Food Chem., 255: 380-389. https://doi.org/10.1016/j.foodchem.2018.01.184

-Moon SS, Kim D, Kim IS, Ham JS, Park BY, Jang A (2014). Alteration of porcine serum albumin levels in pork meat by marination in kiwi or pineapple juice and subsequent pan broiling. Korean J. Food Sci. Anim. Resour., 34: 355. https:// doi.org/10.5851/kosfa.2014.34.3.355

- Morais V, Massaldi H (2012). A model mechanism for protein precipitation by caprylic acid: Application to plasma purification. Biotechnol. Appl. Biochem., 59: 50-54. https:// doi.org/10.1002/bab.68

- Nida L, Pisestyani H, Basri C (2020). Studi Kasus: Pemalsuan Daging Sapi dengan Daging Babi Hutan di Kota Bogor. J. Kajian Vet., 8: 121-130. https://doi.org/10.35508/jkv. v8i2.2326 
- Oh JW, Pyun BY, Choung JT, Ahn KM, Kim CH, Song SW, Son JA, Lee SY, Lee SI (2004). Epidemiological change of atopic dermatitis and food allergy in school-aged children in Korea between 1995 and 2000. J. Korean Med. Sci., 19: 716723. https://doi.org/10.3346/jkms.2004.19.5.716

- Ramos MC, Canseco GC (1993). Hypersensitivity to common allergens in the central region of Coahuila. Rev. Alerg. Mex., 40: 150.

-Rentzos G, Johanson L, Goksör E, Telemo E, Lundbäck B, Ekerljung L (2019). Prevalence of food hypersensitivity in relation to $\mathrm{IgE}$ sensitisation to common food allergens among the general adult population in West Sweden. Clin. Transl. Allergy, 9: 22. https://doi.org/10.1186/s13601-0190261-z

- Rohman A, Erwanto Y, Man YBC (2011). Analysis of pork adulteration in beef meatball using Fourier transform infrared (FTIR) spectroscopy. Meat Sci., 88: 91-95. https:// doi.org/10.1016/j.meatsci.2010.12.007

-Sadeghi S, Aghebati-Maleki L, Nozari S, Majidi J (2018). A methodological approach for production and purification of polyclonal antibody against dog IgG. Vet. Res. Forum, pp. 13-18.

-Shawki A, El-Baky A, Ahmed M, Linjawi MH, Aljaddawi AA,
Redwan EM (2017). Simple protocol for immunoglobulin G Purification from Camel "Camelus dromedarius" serum. Open Life Sci., 12: 143-155. https://doi.org/10.1515/biol2017-0017

-Song Q, Chen Y, Zhao L, Ouyang H, Song J (2019). Monitoring of sausage products sold in Sichuan Province, China: Afirst comprehensive report on meat species' authenticity determination. Sci. Rep., pp. 9. https://doi.org/10.1038/ s41598-019-55612-x

-Ulca P, Balta H, Çağın İ, Senyuva HZ (2013). Meat species identification and Halal authentication using PCR analysis of raw and cooked traditional Turkish foods. Meat Sci., 94: 280-284. https://doi.org/10.1016/j.meatsci.2013.03.008

-Wakayama T, Kato Y, Utsumi R, Tsuji A, Iseki S (2006). A time-and cost-saving method of producing rat polyclonal antibodies. Acta Histochem. Cytochem., 39: 79-87. https:// doi.org/10.1267/ahc.06003

-Yin R, Sun Y, Wang K, Feng N, Zhang H, Xiao M (2020). Development of a PCR-based lateral flow strip assay for the simple, rapid, and accurate detection of pork in meat and meat products. Food Chem., pp. 126541. https://doi. org/10.1016/j.foodchem.2020.126541 